\title{
Pengaruh Radikal Bebas Terhadap Proses Inflamasi pada Penyakit Paru Obstruktif Kronis (PPOK)
}

\section{Effect of Free Radicals on Inflammatory Process in Chronic Obstructive Pulmonary Disease (COPD)}

\author{
Rivan Virlando Suryadinata*1
}

\begin{abstract}
ABSTRAK
Latar Belakang : Penyakit PPOK ditimbulkan akibat paparan asap rokok yang terus menerus. Radikal bebas yang dibawa oleh asap rokok terhirup masuk kedalam saluran napas dapat menimbulkan eksaserbasi. Tujuan : Menjelaskan proses eksaserbasi yang dipengaruhi oleh proses inflamasi pada penderita PPOK akibat peningkatan radikal bebas.

Ulasan : Pada tubuh manusia, radikal bebas merupakan produk hasil metabolisme dari sel normal. Pada keadaan normal, Radikal bebas berfungsi sebagai salah satu sistem pertahanan tubuh. Radikal bebas dapat berupa Reactive Oxygen Spesies (ROS) dan Reactive Nitrogen Spesies (RNS), keduanya dapat diperoleh melalui dari dalam (endogen) maupun dari luar tubuh (eksogen). Pada keadaan patologis akibat paparan asap rokok menimbulkan ketidakseimbangan antara jumlah radikal bebas yang dihasilkan dalam tubuh sehingga dapat mengakibatkan terjadinya stress oksidatif.

Kesimpulan: Peningkatan jumlah radikal bebas secara langsung akan berpengaruh pada mediator inflamasi pada tubuh. Peningkatan radikal bebas akan memicu proses inflamasi secara lokal pada saluran napas dan sistemik sehingga meningkatkan angka kejadian eksaserbasi pada penderita PPOK.
\end{abstract}

Kata Kunci: radikal bebas, PPOK, inflamasi, rokok

\begin{abstract}
S
Background: Chronic Obstructive Pulmonary Disease is diseases caused by exposure to cigarette smoke. Cigarette smoke carries free radicals into the airways which can lead to acute exacerbations in patients. Objectives: explanation of inflammatory processes in the airways in patients with PPOK due to an increase in free radicals.

Discusion: In the human body, free radicals are metabolic products from normal cells and function as one of the body's defense systems. Free radicals can be Reactive Oxygen Species (ROS) and Reactive Nitrogen Species (RNS), both of which can be obtained from the inside (endogenous) or from outside the body (exogenous). In the pathological, exposure to cigarette smoke causes an imbalance between the amount of free radicals produced in the body so that it can lead to oxidative stress.

Conclusion: An increase in the number of free radicals will directly affect inflammatory mediators in the body. Increased free radicals will trigger the inflammatory process locally in the airways and systemically, so increasing the rate of exacerbations in COPD patients.
\end{abstract}

Keywords: free radical, COPD, inflammation, cigarette smoke 
*Koresponden:

rivan.virlando.suryadinata@gmail.com

${ }^{1}$ Departemen Kesehatan Masyarakat

Fakultas Kedokteran - Universitas Surabaya, Indonesia

\section{PENDAHULUAN}

Penyakit Paru Obstruktif Kronik (PPOK) merupakan kondisi penyakit yang dapat dicegah dan diobati, serta ditandai dengan adanya keterbatasan aliran udara yang bersifat progresif dan berkaitan dengan respons inflamasi kronis pada saluran napas dan paru-paru akibat partikel atau gas yang beracun ${ }^{1}$. Angka kejadian PPOK telah mencapai lebih dari 5 persen total populasi dan berhubungan dengan peningkatan morbiditas dan mortalitas. Di Amerika telah menjadi penyebab kematian peringkat ketiga dengan angka kematiannya mencapai lebih dari 120.000 orang setiap tahun ${ }^{2}$. Pada tahun 2020 diperkirakan PPOK akan menjadi penyebab kematian ketiga di dunia setelah penyakit jantung iskemik dan penyakit serebrovaskular ${ }^{3}$.

Di Indonesia, angka kejadian PPOK telah mencapai $3,7 \%$ dari total populasi. Pada tahun 2013, angka mortalitas PPOK telah mencapai peringkat ke 6 dari 10 penyebab kematian. Prevalensi PPOK tertinggi ditemukan di propinsi Nusa Tenggara Timur (10\%), Sulawesi Tengah $(8 \%)$, serta Sulawesi Barat dan Sulawesi Selatan $(6,7 \%)^{4}$.

Asap rokok menjadi faktor risiko utama penyebab terjadinya penyakit PPOK. Asap rokok mengandung sekitar $10^{15}-10^{17}$ oksidan atau radikal bebas dan sekitar 4700 bahan kimia yang berbahaya, termasuk aldehydes/carbonyls, $\mathrm{NO}_{2}$, dan $\mathrm{SO}_{2}$. Paparan asap tembakau dan asap yang berasal dari pembakaran bahan bakar biomassa juga dapat menyebabkan stres oksidatif dan memicu respons inflamasi pada paru ${ }^{5}$.

\section{DISKUSI}

\section{Penyakit Paru Obstruksi Kronis}

Peradangan kronis pada saluran napas memiliki peran penting dalam kejadian PPOK yang disebabkan oleh peningkatan jumlah sel goblet, hiperplasia mukus, fibrosis dan penyempitan saluran udara. Peningkatan enzim proteolitik (MMP-2, MMP-9, MMP-12, cathepsin $\mathrm{K}, \mathrm{L}$ dan $\mathrm{S}$ dan neutrophil elastase) diakibatkan karena adanya peradangan dan stres oksidatif yang terjadi pada PPOK. Hiper sekresi lendir dan inflamasi pada sekitar kelenjar submukosa dikaitkan dengan peningkatan kejadian eksaserbasi dan tingkat keparahan peradangan pada saluran udara ${ }^{3}$.

Respon peradangan pada saluran udara perifer dan parenkim paru akibat paparan asap rokok akan dapat menyebabkan iritasi pada saluran napas. Pada pathogenesis terjadinya PPOK, makrofag memiliki peranan utama. Makrofag merupakan salah satu sistem pertahanan tubuh yang dapat melepaskan mediator inflamasi dan faktor kemotaktik berupa tumor necrosis factor- $\alpha$ (TNF- $\alpha$ ), interleukin IL -6, interleukin IL -8, leukotriene LTB4, Monocyte Chemotactic Peptide (MCP)-1 dan spesies oksigen reaktif, serta memicu pengeluaran enzim proteolitik terutama MMP-9 dan MMP-12. Pengaruh faktor kemotaktik yang disekresikan terutama IL-8 dan LTB-4, dapat merangsang pergerakan neutrofil menuju saluran pernapasan dan menyebabkan hipersekresi mukus pada submukosa dan sel goblet pada saluran napas ${ }^{6,7}$.

PPOK dapat diklasifikasikan berdasarkan tingkat keparahan fungsi paru-paru yaitu emfisema, bronkitis kronis dengan obstruksi saluran napas, dan penyakit saluran napas, tetapi kebanyakan pasien menunjukkan kombinasi. Emfisema ditandai dengan kerusakan septa alveolar, hilangnya elastisitas, pembesaran ruang udara pada alveoli, dan hilangnya difusi gas. Bronkitis kronis mempengaruhi saluran udara yang lebih besar melalui peradangan saluran napas (peran neutrofil, makrofag, dan sel-sel imun-inflamasi lainnya), hiperplasia sel goblet 
dan hipersekresi lendir. Selain penurunan fungsi paru, pada pasien PPOK akan mengalami produksi sputum kronis yang berlebih (hipersekresi lendir), batuk, dan sering dispnea. Penyakit saluran napas kecil terutama mempengaruhi bronkiolus yang disebabkan peradangan saluran napas dan metaplasia sel Clara. Patogenesis PPOK melibatkan beberapa proses, seperti stres oksidatif, peradangan paruparu, peradangan sistemik, ketidakseimbangan protease / antiprotease, penurunan sistem imun, apoptosis, remodeling matriks ekstraseluler, gangguan perbaikan jaringan, perubahan proliferasi sel, dan penuaan seluler atau penuaan dini. Semua proses ini terkait dengan stres oksidatif sistemik dan paru-paru ${ }^{8}$.

\section{Radikal Bebas}

Radikal bebas didefinisikan sebagai molekul yang membawa satu atau lebih elektron tak berpasangan dan mampu eksis secara independen. Radikal bebas memiliki jumlah elektron ganjil sehingga berumur pendek, sangat reaktif, dan tidak stabil. Radikal bebas dapat bereaksi dengan cepat dengan molekul lain dengan menangkap elektron untuk menjadi stabil. Radikal bebas akan menjadi seimbang dengan mengambil elektron pada molekul terdekat. Sementara itu molekul yang diserang akan menjadi radikal bebas yang disebabkan kehilangan elektron dan memulai reaksi berantai sehingga menyebabkan kerusakan pada sel. Contoh radikal bebas adalah radikal termasuk Superoksida $\left(\mathrm{O}_{2}{ }^{\circ}\right)$, Radikal oksigen $\left(\mathrm{O}_{2}{ }^{*}\right)$, Hidroksil $(\mathrm{OH} \cdot)$, Alkoxyradical $(\mathrm{RO} \cdot)$, radikal Peroxyl (ROO·), Nitrat oxide (nitrogen monoksida) (NO*) dan nitrogen dioxide $\left(\mathrm{NO}_{2}{ }^{\circ}\right)$. Spesies oksigen reaktif (ROS) adalah turunan radikal seperti singlet oksigen dan hidrogen peroksida 9 .

Reaktivitas tinggi dari radikal ini adalah karena adanya satu elektron tak berpasangan sehingga cenderung menyumbangkannya atau untuk mendapatkan elektron lain untuk mencapai stabilitas. Spesies non radikal termasuk hidrogen peroksida $\left(\mathrm{H}_{2} \mathrm{O}_{2}\right)$, asam hipoklorit $(\mathrm{HOCl})$, asam hypobromous $(\mathrm{HOBr})$, ozon $\left(\mathrm{O}_{3}\right)$, oksigen singlet $\left({ }^{1} \mathrm{O}_{2}\right)$, asam nitrat
$\left(\mathrm{HNO}_{2}\right)$, nitrosil kation $\left(\mathrm{NO}^{+}\right)$, anion nitroksil $\left(\mathrm{NO}^{-}\right.$ ), dinitrogen trioksida $\left(\mathrm{N}_{2} \mathrm{O}_{3}\right)$, dinitrogen tetraoksida $\left(\mathrm{N}_{2} \mathrm{O}_{4}\right)$, nitronium (nitryl) kation $\left(\mathrm{NO}_{2}{ }^{+}\right)$, peroksida organik $(\mathrm{ROOH})$, aldehid (HCOR) dan peroksinitrit (ONOOH). Spesies non radikal ini bukan radikal bebas tetapi dengan mudah dapat menyebabkan reaksi radikal bebas pada organisme hidup ${ }^{10}$.

Radikal bebas pada tubuh manusia tidak hanya diperoleh dari endogen (hasil produk metabolisme sel secara normal), namun juga dapat diperoleh dari sumber eksogen (polusi udara, asap kendaraan, asap rokok dsb). Pada sumber endogen, metabolisme sel normal merupakan sumber utama unruk menghasilkan Radical Oxygen Species (ROS) dan memainkan peran penting dalam aktivasi jalur sinyal pada sel yang mempengaruhi metabolisme intra dan ekstraseluler. Sebagian besar ROS diproduksi dalam sel melalui mitokondria. Selama reaksi metabolisme endogen, ROS akan dihasilkan oleh sel aerobik (berupa anion superoksida, radikal hidroksil dan hidrogen peroksida) sebagai produk dari biologis oksigen molekuler. Dalam situasi hipoksia, mitokondria juga dapat menghasilkan nitrit oksida (NO) yang menghasilkan Radical Nitrogen Species (RNS). Radikal bebas akan memicu timbulnya spesies reaktif tambahan lainnya, misalnya reaktif aldehidamalondialdehida dan 4-hidroksinonenal, akibat dari menginduksi peroksidasi lipid yang berlebihan. Lipid dan protein adalah target penting untuk serangan oksidatif dan perubahan molekul-molekul ini dapat meningkatkan proses mutagenesis ${ }^{11}$. Radikal bebas yang diperoleh dari sumber eksogen dapat berupa polusi lingkungan, asap kendaraan, dan asap rokok. Berbagai macam polusi lingkungan dapat menimbulkan resiko kesehatatan, seperti pencemaran lingkungan yang berasal dari logam (arsenik, tembaga, dan timbal), senyawa halogenasi (kloroform dan karbon tetraklorida), polutan udara (ozon dan sulfur dioksida, sulfur trioksida, hidrazin) dan berbagai jenis obat (arsenik trioksida dan hydralazine) yang sering digunakan sebagai pengobatan kanker dan hipertensi ${ }^{12}$.

Arsenik anorganik sering didapatkan sebagai kontaminan pada tanah, air dan udara. 
Senyawa tersebut mudah diserap pada tubuh manusia dan terbukti dapat menginduksi pembentukan tumor di kandung kemih, prostat, hati dan kulit ${ }^{13,14}$. Senyawa haloalkana terbentuk dari reaksi klorin dengan alkana yang telah digunakan dalam industri sebagai pelarut, pembersih, anestesi, dan sebagai antiseptik. Beberapa haloalkan ditemukan sebagai kontaminan dalam air minum dan diklorinasi pada kolam renang. Haloalkana secara umum bersifat sangat hepatotoksik dan dikenal sebagai karsinoge ${ }^{15}$. Sedangkan masalah utama polusi udara yang dapat memicu radikal bebas adalah smog. Senyawa tersebut berasal dari bentuk polusi udara yang dihasilkan oleh reaksi sinar matahari dengan hidrokarbon, senyawa nitrogen, ozon dan gas lainnya terutama dilepaskan dalam knalpot mobil. Berbagai senyawa berupa oksida nitrat, belerang dioksida dan ozon dikenal oksidan dan dapat menyebabkan kerusakan organ dan seluler melalui pembangkitan spesies radikal bebas. Nitrit oksida cepat bereaksi dengan molekul oksigen untuk menghasilkan peroksinitrit yang sangat reaktif serta dapat mengoksidasi DNA, protein dan lipid ${ }^{16}$.

Asap rokok juga menjadi faktor utama yang paling berpengaruh terhadap peningkatan radikal bebas dalam tubuh. Secara alamiah radikal bebas akan dinetralisir oleh antioksidan sehingga menjadi stabil. Pada konsentrasi rendah sampai sedang mereka berfungsi dalam proses sel fisiologis, namun pada konsentrasi tinggi, mereka menghasilkan modifikasi yang merugikan pada komponen sel seperti lipid, protein dan DNA $^{17}$. Keadaan patologis terjadi ketika jumlah radikal bebas dan antioksidan dalam tubuh terjadi ketidakseimbangan. Peningkatan jumlah radikal bebas dalam tubuh akan memicu terjadinya stress oksidatif dan merangsang peroksidasi pada sel, sehingga dapat menimbulkan kerusakan dan kematian pada sel tubuh $^{18}$.

Stress oksidatif merupakan ketidakseimbangan antara manifestasi sistemik dari radikal bebas berupa ROS terhadap kemampuan sistem tubuh dalam menetralkan dan memperbaiki kerusakan yang ditimbulkan oleh radikal bebas ${ }^{19}$. Sebagian besar kerusakan pada sel tidak terjadi secara langsung, namun disebabkan oleh $\mathrm{ROS}$ yang dihasilkan seperti $\mathrm{O}_{2}{ }^{-}$ (radikal superoksida), $\mathrm{OH}$ (radikal hidroksil) dan $\mathrm{H}_{2} \mathrm{O}_{2}$ (hidrogen peroksida). Pada manusia, peningkatan stress oksidatif dapat menyebabkan gangguan metabolisme normal dan memicu terjadinya berbagai macam penyakit seperti kanker, parkinson, alzheimer, aterosklerosis, gagal jantung dan infark miokard. Pada jumlah yang tidak berlebih, radikal bebas berguna sebagai sistem pertahanan tubuh dengan cara menyerang dan membunuh patogen ${ }^{20}$.

\section{Pengaruh Radikal bebas pada PPOK Terhadap Peradangan Saluran Napas}

Proses inflamasi kronis pada PPOK melibatkan kekebalan bawaan dan adaptif dan paling berpengaruh pada dinding bronkus saluran udara kecil. Karakteristik PPOK adalah adanya eksaserbasi akut yang biasanya dikaitkan dengan peningkatan peradangan. Penyebab eksaserbasi yang penting termasuk infeksi (bakteri, virus dan gabungan virus atau bakteri) dan faktor lingkungan ${ }^{21}$. Eksaserbasi PPOK sangat terkait dengan kematian, rawat inap dan penurunan status fungsional. Merokok adalah faktor risiko utama untuk PPOK tetapi paparan lainnya terutama akibat dari ventilasi rumah yang buruk $^{22}$. Obstruksi saluran napas merupakan tanda adanya peradangan yang disebabkan oleh akumulasi inflamasi lendir eksudat dalam lumen dan peningkatan volume jaringan dinding bronkus. Peningkatan dalam volume jaringan dinding bronkus ditandai oleh infiltrasi dinding oleh makrofag atau neutrofil dan sel imun inflamasi adaptif (CD4, CD8 dan limfosit B) yang membentuk folikel limfoid ${ }^{23}$.

Faktor-faktor yang mendorong peradangan pada PPOK adalah autoimunitas, partikel asing atau logam berat dari merokok dan infeksi bakteri kronis semuanya dapat memiliki peran. Faktor utama yang terkait dengan peradangan paru pada PPOK adalah autoimunitas. Penyakit autoimun yang ditandai dengan kehadiran antibodi antielastin dan Thelper tipe 1. Bakteri yang paling umum terdapat pada paru-paru pasien dengan PPOK adalah 
nontypeable Haemophilus influenzae (NTHi). Bakteri ini juga telah terbukti dapat mengaktifkan Sel T paru-paru dan menyebabkan peningkatan ekspresi reaktif oksigen spesies dan protease pada pasien dengan $\mathrm{PPOK}^{24}$.

\section{Pengaruh radikal bebas pada PPOK terhadap peradangan sistemik}

Paru memiliki luas permukaan sebesar 80 $100 \mathrm{~m}^{2}$ dan volume pernafasan mencapai 10.000 hingga $20.000 \mathrm{~L} /$ hari yang mengakibatkan paruparu sangat rentan terhadap radikal bebas. Asap rokok memiliki banyak radikal bebas dan memicu penurunan kapasitas antioksidan bahkan dalam plasma. Radikal bebas dapat menonaktifkan inhibitor a1-proteinase sehingga mengurangi kemampuannya untuk mengikat substrat seperti elastase dari neutrofil. Proses peradangan akan menyebabkan stres karena berpotensi memproduksi ROS yang berlebihan ${ }^{25}$.

Perubahan patofisiologis yang terjadi pada paru dengan PPOK akan menyebabkan inflamasi sistemik. Proses yang berperan dalam peradangan sistemik adalah hipoksia dan hiperinflasi. Hipoksia merupakan masalah umum pada PPOK, pasien dengan PPOK ringan akan mengalami hipoksia dan terjadi peningkatan kadar IL- $6^{26}$. Selain itu, adanya korelasi antara kadar serum TNF- $\alpha$ dan derajat hipoksemia pada pasien PPOK. Kejadian hipoksia juga dapat menyebabkan peningkatan TNF- $\alpha$, Macrophage Inflammatory Protein (MIP) -1 b, dan Monocyte Chemoattractant Protein (MCP)-1 MrnA. Hiperinflasi juga terjadi pada penderita PPOK akibat dari obstruksi jalan napas kronis. Hiperinflasi dapat menyebabkan peningkatan sistemik TNF- $\alpha$ dan IL-8, IL-6, dan IL-1 b secara sistemik. Peningkatan hiperinflasi dapat memprediksi kematian pada pasien PPOK $^{27}$.

Peningkatan inflamasi sistemik berhubungannya dengan PPOK, yang sebagian merupakan akibat proses penuaan normal. PPOK adalah penyakit kronis, yang berkembang sangat lambat, dengan mayoritas pasien berusia tua. Penuaan normal dikaitkan dengan peningkatan inflmasi sistemik tingkat rendah, termasuk produksi sitokin seperti IL- 6 dan TNF- $\alpha$ ditambah dengan adanya peningkatan oksida nitrat dan spesies oksigen reaktif ${ }^{28}$. Namun, Proses menua juga bukan merupakan satu-satunya penyebab inflmasi sistemik pada PPOK. Beberapa penelitian yang membandingkan adanya inflamasi sistemik pada pasien PPOK dengan

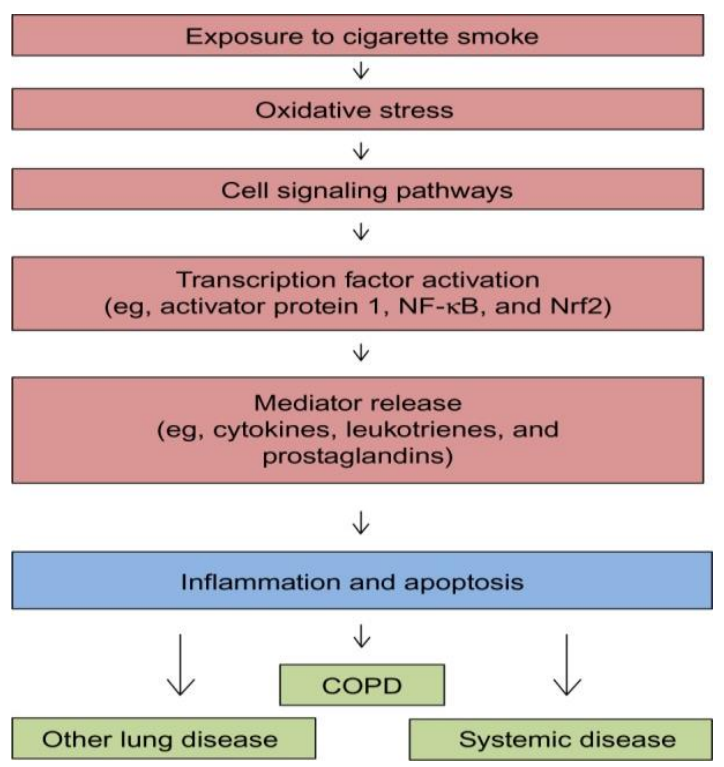

Gambar 1. Proses inflamasi akibat paparan asap rokok ${ }^{32}$ 
kelompok control non PPOK dengan usia yang sama, didapatkan bahwa memiliki tingkat inflamasi yang lebih besar Sebagai contoh,kelompok kontrol yang non PPOK dengan pasien PPOK terjadi peningkatan inflamasi sistemik, termasuk produksi TNF- $\alpha^{29}$. Selain itu, peningkatan radikal bebas pada perokok ${ }^{30}$ dan penurunan sistem imun tubuh ${ }^{31}$. Hal tersebut akan memicu timbulnya berbagai macam penyakit sistemik lainnya seperti rheumatoid arthritis, diabetes melitus, neurodegeneratif, kanker, penyakit kardiovaskuler dan asma ${ }^{11,32}$

Penelitian yang dilakukan oleh Chen et al., 2017 menunjukkan peningkatan eksaserbasi PPOK berhubungan dengan peningkatan mediator inflamasi dan peradangan saluran napas. Peningkatan tingkat biomarker berhubungan dengan keparahan penyakit seperti tingkat eksaserbasi, lama inap di rumah sakit, dan mortalitas ${ }^{33}$. Selain itu, Kadar serum IL6 menjadi lebih tinggi pada virus dibanding non virus. koinfeksi rhinovirus dan $\mathrm{H}$. influenza pada penderita PPOK juga dapat meningkatkan kejadian eksaserbasi ${ }^{34}$.

\section{KESIMPULAN}

Asap rokok mengandung berbagai bahan kimia berbahaya yang berpotensi mengganggu kesehatan. Bahan kimia dari asap rokok yang masuk kedalam saluran napas mengandung berbagai jenis radikal bebas seperti ROS (Reactive Oxygen Species). Radikal bebas yang masuk kedalam saluran napas dapat dinetralisir oleh antioksidan yang dihasilkan dalam tubuh. Jumlah radikal bebas dan antioksidan yang tidak seimbang dapat mengakibatkan stress oksidatif pada sel sehingga memicu terjadinya peroksidase lipid. Asap rokok juga berkontribusi pada ketidakseimbangan oksidan / antioksidan karena spesies oksigen reaktif eksogen (ROS). Selain itu, proses inflamasi dan disfungsi mitokondria akibat radikal bebas juga dapat berkontribusi terhadap perkembangan penyakit PPOK.

Pada pasien PPOK
peradanyan, proses
peningkatan jumlah sel goblet akibat paparan

asap rokok akan semakin memperburuk kesehatan. Hal ini dikarenakan terjadinya penyempitan saluran napas sehingga menimbulkan eksaserbasi akut. Faktor lain yang memperberat peradangan pada PPOK adalah infeksi bakteri dan faktor lingkungan. Proses peradangan sistemik juga dapat terjadi pada penderita PPOK yang dipengaruhi oleh hipoksia dan hiperinflasi paru. Hal ini akan semakin meningkatkan resiko mortalitas pada penderita PPOK.

\section{ACKNOWLEDGEMENT}

Penulis mengucapkan terima kasih kepada Trias Mahmudiono yang telah memberikan bimbingan dan pengajaran selama perkuliahan di Program Pendidikan doktor, Fakultas Kesehatan Masyarakat, Universitas Airlangga.

\section{REFERENSI}

1. Disease Global Initiative For Chronic Obstructive Lung. Pocket Guide To Copd Diagnosis, Management, And Prevention A Guide for Health Care Professionals 2017 EDITION.

2. Miniño, B. A. M., Murphy, S. L. \& Xu, J. National Vital Statistics Reports Deaths: Final Data for 2008. 59, (2011).

3. Angelis, N., Porpodis, K., Zarogoulidis, P., Spyratos, D., Kioumis, I., Papaiwannou, A., Pitsiou, G. et al. Airway inflammation in chronic obstructive pulmonary disease. $J$. Thorac. Dis. 6, 4-9 (2014).

4. Badan Penelitian dan Pengembangan Kesehatan. Riset Kesehatan Dasar (RISKESDAS) 2013. Lap. Nas. 2013 1-384 (2013). doi:1 Desember 2013

5. Rahman, I. Pharmacological Antioxidant Strategies As Therapeutic Interventions For COPD. Biochim Biophys Acta 1822, 714-728 (2012).

6. Barnes, P. J., Shapiro, S. D. \& Pauwels, R. A. Chronic Obstructive Pulmonary Disease: Molecular and Cellular Mechanisms. Eur. Respir. J. 22, 672-688 (2003). 
7. Suryadinata, R. V. et al. Pengaruh perubahan hiperplasia sel goblet selama 28 hari paparan asap rokok dengan pemberian antioksidan superoxide dismutase. Indones. J. Public Heal. 11, 6068 (2016).

8. Yao, H. \& Rahman, I. Current concepts on oxidative/carbonyl stress, inflammation and epigenetics in pathogenesis of chronic obstructive pulmonary disease. Toxicol. Appl. Pharmacol. 254, 72-85 (2011).

9. Reuter, S., Gupta, S. C., Chaturvedi, M. M. \& Aggarwal, B. B. Oxidative stress, inflammation, and cancer: how are they linked? Free Radic. Biol. Med. 49, 16031616 (2010).

10. Lobo, V., Patil, A., Phatak, A. \& Chandra, $\mathrm{N}$. Free radicals, antioxidants and functional foods: Impact on human health. Pharmacogn. Rev. 4, 118-126 (2010).

11. Phaniendra, A., Jestadi, D. B. \& Periyasamy, L. Free radicals: properties, sources, targets, and their implication in various diseases. Indian J. Clin. Biochem. 30, 11-26 (2015).

12. Sinha, B. . Roles of Free Radicals in the Toxicity of Environmental Pollutants and Toxicants. J. Clin. Toxicol. s12, 1-3 (2013).

13. Kojima, C. et al. Requirement of arsenic biomethylation for oxidative DNA damage. J. Natl. Cancer Inst. 101, 16701681 (2009).

14. Obinaju, E. B. Mechanisms of arsenic toxicity and carcinogenesis. Afrincan J. Biochem. Res. 3, 232-237 (2009).

15. Weber, L. W. D., Boll, M. \& Stampfl, A. Hepatotoxicity and Mechanism of Action of Haloalkanes: Carbon Tetrachloride as a Toxicological Model. Crit. Rev. Toxicol. 33, 105-136 (2003).

16. Ranguelova, K. et al. Formation of reactive sulfite-derived free radicals by the activation of human neutrophils: an ESR study. Free Radic. Biol. Med. 52, 1264-1271 (2012).

17. Valko, M. et al. Free radicals and antioxidants in normal physiological functions and human disease. Int. J. Biochem. Cell Biol. 39, 44-84 (2007).

18. Suryadinata, R. V., Wirjatmadi, B. \& Adriani, M. Efektivitas Penurunan Malondialdehyde dengan Kombinasi Suplemen Antioksidan Superoxide Dismutase Melon dan Gliadin Akibat Paparan Rokok. Glob. Med. Helath Commun. 5, 79-83 (2017).

19. Birben, E., Sahiner, U. M., Sackesen, C., Erzurum, S. \& Kalayci, O. Oxidative stress and antioxidant defense. World Allergy Organ. J. 5, 9-19 (2012).

20. Ozougwu, J. . The Role of Reactive Oxygen Species and Antioxidants in Oxidative Stress. Int. J. Res. Pharm. Biosci. 3, 1-8 (2016).

21. Suissa, S., Dell'Aniello, S. \& Ernst, P. Longterm natural history of chronic obstructive pulmonary disease: severe exacerbations and mortality. Thorax 67, 957-963 (2012).

22. Vestbo, J. et al. Global strategy for the diagnosis, management, and prevention of chronic obstructive pulmonary disease GOLD executive summary. Am. J. Respir. Crit. Care Med. 187, 347-365 (2013).

23. Cosio, M. G., Saetta, M. \& Agusti, A. Immunologic Aspects of Chronic Obstructive Pulmonary Disease. N. Engl. J. Med. 360, 2445-2454 (2009).

24. King, P. T. et al. Lung T-cell responses to nontypeable Haemophilus influenzae in patients with chronic obstructive pulmonary disease. J. Allergy Clin. Immunol. 131, 1314-1321.e14 (2013).

25. Domej, W., Oettl, K. \& Renner, W. Oxidative stress and free radicals in COPD--implications and relevance for treatment. Int. J. Chron. Obstruct. Pulmon. Dis. 9, 1207-1224 (2014).

26. Sabit, R., Thomas, P., Shale, D. J., Collins, P. \& Linnane, S. J. The effects of hypoxia on markers of coagulation and systemic inflammation in patients with COPD. Chest 138, 47-51 (2010).

27. Pini, L., Valsecchi, A., Boni, E., Guerini, M., 
Tantucci, C. Acute dynamic hyperinfl ation and systemic infl ammation in stable COPD patients. in Am J Respir Crit Care Med 181 (2010).

28. Sharma, G., Hanania, N. A. \& Shim, Y. M. The aging immune system and its relationship to the development of chronic obstructive pulmonary disease. Proc. Am. Thorac. Soc. 6, 573-580 (2009).

29. Rabinovich, R. A. et al. Increased tumour necrosis factor- $\alpha$ plasma levels during moderate-intensity exercise in COPD patients. Eur. Respir. J. 21, 789-794 (2003).

30. Pratiwi, S. R. et al. Asupan Vitamin C dan E dengan SQ-FFQ terhadap Fungsi Paru Perokok. 14, 101-107 (2018).

31. Suryadinata, R. V., Lorensia, A. \& Sari, R. K. Differences in Nutrition Food Intake and Body Mass Index between Smoker and Non-smoker in Adult. Indones. J. Clin. Pharm. 6, 171-180 (2017).

32. Fischer, B. M., Voynow, J. A. \& Ghio, A. J. COPD: balancing oxidants and antioxidants. Int. J. Chron. Obstruct. Pulmon. Dis. 10, 261-276 (2015).

33. Chen, H., Wang, D., Bai, C., Wang, X. Proteomics-based biomarkers in chronic obstructive pulmonary disease. J Proteome Res 9, 2798-2808 (2010).

34. Kawamatawong, T., Apiwattanaporn, A. \& Siricharoonwong, W. Serum inflammatory biomarkers and clinical outcomes of COPD exacerbation caused by different pathogens. Int. J. Chron. Obstruct. Pulmon. Dis. 12, 1625-1630 (2017). 